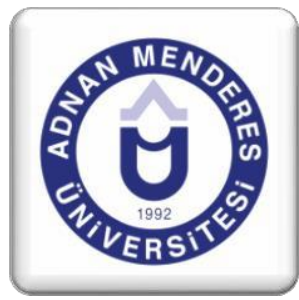

\title{
Stratejik Bir Tercih Olarak Terörizm Terör Paralaksı
}

\author{
Ŏguzhan ERGüN ${ }^{1}$
}

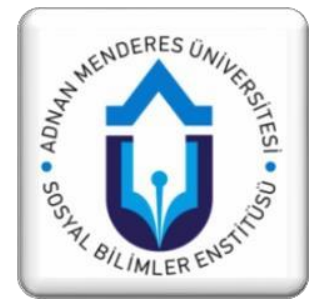

\section{ÖZET}

Türkiye-AB ilişkilerinde son dönemde terör kavramına ilişkin olarak yaşanan ve Türkiye'nin dış politika üretme sürecinde sürtünme etkisi yaratan dar ve geniş tanımlama tartışması uluslararası alanda giderilemeyen bir paralaksı taraflar arasında sorunsallaştırmışıı. Gözlemcinin konumundaki değişiklik veya tek eksenli bakışıyla sanal kaymaya uğrayan olgu o görüşle yorumlanarak dayatılmaktadır. Negatif asimetri içinde yaşayan toplulukların (görece güçsüzlerin) tarih boyunca uyguladıkları dolaylı tutum stratejisi terörizm, hibritleşen savaş ortamında güçlülerin başvurduğu başat bir stratejik tutuma dönüşmüştür. Küresel düzeyde ortaya çıkan gelişmeler nihayetsiz Küresel İç Savaş stratejisi olarak adlandırılmaya başlamıştır. Terörizme bakış ve tanımlarda paralaksın ortaya çıkmasında taraflı stratejik duruş kadar taraflı medyanın konuyu çerçevelemesi, hukuki ve akademik kavramsallaştırmadaki soyutlamalar ya da genellemeler önemli yer tutmaktadır. Bu çalışmada Terör ve Terörizm kavramlarının ontolojisi strateji bağlamında tartışılmaktadır.

Anahtar Kelimeler: Terörizm Stratejisi, Küresel İç Savaş, Rehine stratejileri, Holistik Operasyonlar, Siyasal HIV.

\section{Terrorism As a Strategic Choice}

\section{Terror Parallax}

\begin{abstract}
The recent discussions on the narrow and broad definition of terror that have become a current issue in TurkeyEU relations and consequently created a friction effect in Turkey's foreign policy development process have problematized a parallax between the parties that lacks solution in the international area. Changes in the position of the observer or facts suffering virtual slip by an uniaxial view are imposed with an interpretation made according to that point of view. Terrorism, as an indirect behavior strategy implemented throughout history by societies (relatively weak groups) that live in negative asymmetry, has turned into a dominant strategic behavior which the strong groups resort to in the current hybridized war environment. Developments all around the globe have begun to be called as endless Global Civil War strategy. An important place in the emergence of a parallax in the view to and definitions of terrorism is held by not only partial strategic standing, but also the issue being framed by partial media as well as abstractions in legal and academic conceptualizations or generalizations. In this paper, the ontology of Terror and Terrorism as a concept is discussed in the context of strategy.
\end{abstract}

Keywords: Terrorist strategy, Global Civil War, Urban Terror, Hostage strategies, Holistic Operations, Political HIV.

\footnotetext{
${ }^{1}$ Dr. Oğuzhan ERGÜN, E. Top. Kur. Kd. Alb. İKÇÜ SBE Öğretim Görevlisi, oguzhanergun@gmail.com.
} 


\section{Notlar:}

Stratejik Sürtünme: Carl von Clausewitz : (Reibung- Friktion)“(...)kâğıt üzerinde yakından incelenmesine imkân bulunmayan bir sürü önemsiz şeylerin etkisiyle, olaylar bizi hayal kırıklığına uğratır ve hedefin hayli gerisinde kalırız. Güçlü, çelikten bir irade bu sürtünmenin üstesinden gelir, engelleri yıkar, fakat onlarla birlikte makina da parçalanır”. Clausewitz, 1827 vom Kriege, H.1 Kap. 7, s. 45, 47)

Paralaks: Görülen konum ve gerçek konum arasında fark oluşmasına verilen isimdir.

Çerçeveler: Seçim, vurgu, sunuş ilkeleridir. Var olanla, olup bitenleri, önemli olanı düzenleyecek küçük teorilerden kuruludur. Tod Gitlin, The Whole World Is Watching: Mass Media in the Making and Unmaking of the New Left, Berkeley, Los Angeles, London, University of California Press, 2003, s.6.

\section{Notes:}

Strategic Friction : Carl von Clausewitz :(Reibung- Friction)“(...) through the influence of an infinity of petty circumstances, which cannot properly be described on paper, things disappoint us, and we fall short of the mark. A powerful iron will overcomes this friction, it crushes the obstacles, but certainly the machine along with them". Clausewitz, 1827 vom Kriege, Book 1 Chap. 7, p. 45, 47.

Parallax: Is the name given to the difference in the apparent position and actual position

Frames :Frames are principles of selection, emphasis, presentation. They consist of minor theories that will regulate what exists, what happens, what matters. Tod Gitlin, The Whole World Is Watching: Mass Media in the Making and Unmaking of the New Left, Berkeley, Los Angeles, London, University of California Press, 2003, p.6. 


\section{Giriş}

Sosyal Bilimlerin niteliksel araştırma yöntemi kullanılarak yapılan ve üç yıl süren bir araştırmada, 2500 yıllık zaman diliminde ve dört kültür havzasını kapsayan sahada, 12 klasik stratejistin (stratejin) eserleri incelenmiştir. Stratejinin temel prensiplerinin neler olduğuna yönelik bir sorunun cevabını bulma yönündeki bu araştırmada ilginç sonuçlara ulaşılmıştır. Tespit edilen ve gruplandırılan 153 prensipte, farklı zamanlarda ve farklı kültür kuşaklarında yaşamış stratejistlerce aynı gerçekler ve bilgi vurgulanmaktadır (Maier, 2014). İnsanların veya kavimlerin güç ve zor yöntemleri 2500 yıldır benzer mantığı sürdürmüştür. Terörizm ve eylem kipinin topolojisi sosyal ve siyasi boşluklarda paradoksal mantık ile süregelmektedir. Siyasi maksatlı, organize, holistik, ağ tabanlı, çoklu gerçeklenebilirlik özelliği bu stratejinin hukuk teknikleri ile paranteze alınmasını güçleştirmektedir.

Asimetrik ve dolaylı tutumun başat hale geldiği, gerçeğin bulanıklaştırılarak mecazileştirildiği ve "arayüz" kullanımının siyasi kaosu tetiklediği hegemonik kontrol stratejisi istikrarsızlık üretimi üzerine kurgulanmıştır ve mesele, terörizm ve eylem kipi olan "Terör”ün her zaman birileri için, birilerinin değişik ölçekli siyasi amaçlarına hizmet için üretilmiş olmasıdır.

Savaş ve terörizmin, çağımızda, hasmın ulaşmak istediği nihai jeopolitik resim odaklı, siyasi bir amaçla devlet otoritesine veya devletlere karşı, devletin koruma güçlerinin, sivillerin, insani yaşam kaynaklarının hedef alındığı etki odaklı hareketler toplamında buluşmuş olması ve hibrit savaşların karakteristiğini yansıtmasında yatmaktadır. Kissinger'ın ifadesiyle "Yaşadığımız yüzyıl karşıtlıklar yüzyılıdır" (Kissinger 2011: 15). Bu bağlamda asimetrik küreselleşme ve iç savaşlarla şekillenen içinde yaşadığımız dönemin sorunları makalede strateji tarihi içerikli artzamanlı bir analiz olarak kaleme alınmıştır.

$\mathrm{Bu}$ makalede terörist eylemlerin yıkıcı sonuçları ve ulusal güvenliğe, bölgesel istikrara yönelttiği tehdit nedeniyle, hukukî bir sorun olmaktan ziyade savaş eylemi niteliğinde olduğu ve benzer şekilde terörizme karşı devam eden mücadelenin hukukî bir uygulama değil, devam eden bir savaş olarak görülmesi gerektiği vurgulanmaktadır. Terörizme yönelik olarak bir ülkeye dayatılan hukuki tanımlama şekilleri rakip oyuncuya kendi kuralları ile oyunu oynatma tutumu olarak ele alınmaktadır.

Sosyal Bilimlerin rastgeleyi ve düzensizi, istisnayı, ayrıksılığı (eksantrik) ve sürprizi kontrol altına almaya çalışan soyutlayıcı metodolojisine karşılık stratejik analizler bu tür şeylere özel önem vermektedir (Freedman 2015: 21). Baskın ve sürpriz akılcılığın temel ilkelerinin ihlali üzerine kuruludur. Stratejik mücadeleler mantıksal olarak paradoksal kırılmalar içerebilir ve doğrusal mantık alanından bulanık mantık alanına kayar. Bugün müttefik olanların kısa sürede karşı karşıya gelmesi, karşıtlıkların yan yana gelmesi normal mantığı ihlal etse de bunlara stratejinin paradoksal mantığ 1 açıklama getirebilir. Freedman'ın ifadesiyle "strateji her zaman farklılıkları belirlemek, özel firsatları ya da kırılganlıkları ortaya çıkarmakla ilgilidir. Kritik bir asimetriyi hayati bir avantaj olarak belirleyip zaferi kazanmayı amaç edinir. Farklılıklar, kırılganlıklar ve özel firsatlar Orta Doğu coğrafyasının öznel nitelikleridir

\section{Strateji Kavramı ve Terörizm}

Realist bakış açısından "stratejik doktrin gücü politikaya dönüştüren şey" olup strateji savaş ve barış dönemlerinde hedeflenen amaçlara yönelik politika ve yöntemler tayin edilmesidir. Stratejik hedeflerin belirlenerek bunların ele geçirilmesi ve/veya elde bulundurulmasında 
kimlikler belirleyici davranışsal nedenler üretir. Kimlik ve inançlar çıkarların belirlenme güdüsünü sağlamaktadır. Wendt'in vurguladığı konstrüktivist yönüyle "kimlikler aktörlerin kim ya da ne olduğuna işaret eder... Bir aktör kim olduğunu bilmeden ne istediğini bilemez. Çıkarlar kimlikler gerektirir. Bir davranış, bir aktörün sadece ne istediğiyle değil neye, nasıl ulaşılabileceğinin mümkün olduğu hesabı ile ilgilidir" bu yönü stratejik planlamaya kap1 açmaktadır. "Çıkarlar tamamen kimliklere indirgenemese de kimlik çıkarların yönünü belirler" (Wildawsky: 13,139). Bu açıdan stratejik yön, çıkarların temini ve sürdürülmesini sağlayacak ulusal hedeflerin mekanını işaret eder ve bu da kimlik ve ihtiyaçları ile ilgilidir. Kimlik bunalımlarının stratejik yön kaybını beraberinde getirdiği en belirgin mekân Orta Doğu'dur. Birey ve aktörler ulusal, etnik veya evrensel/dini kimlik algıları arasında kaybolmaktadır.

Stratejiden ulusal stratejiye, buradan ulusal güvenlik stratejisi, ulusal kalkınma stratejisi gibi alt kavramlara uzanan bilgi inşası, çıkarlar ve bunların elde edilmesine yönelik bireysel ve kurumsal planlama yeteneğine dayanır. Stratejik düşünce amaçlar, kaynaklar ve yöntemlerle, siyasi maksadın gerçekleştirilmesi için organize edilmiş gücün kullanımıyla yani yönetimle ilgilidir. Ulusal strateji ulusal çıkarlara ve siyasaya yönelik stratejik mimari içerir. Ulusal çıkarlar ise devlet-toplum bileşik yapılarının- fiziksel olarak varlığını sürdürme, özerklik, ekonomik refah ve kolektif özsayg1- olarak belirlenen dört ihtiyaçtan oluşan -nesnelçıkarlardır. Kimliklerin varlığını sürdürebilmesi bu nesnel çıkarların teminine bağlıdır (Wendt 2016: 289). Nesnel çıkarlar işlevsel zorunluluklardır. Ulusal stratejik plan bu çıkarlara yönelik uzun vadeli ve bütünsel yol haritalarını oluşturmaktadır. Bu yolda uygulanacak eylem tarzı stratejik tutum olarak adlandırılmaktadır.

Stratejik tutum siyasi bir sonuca yönelik eylem tarzı ve sürecidir. Stratejiyi siyaset belirler. Bu bağlamda "Stratejik Etki"nin siyasal değişim üreten araç (Gray 2008: 29) olduğu gerçeği kendisini diğer etkilerden farklı kılar. Diğer bir açıdan bakılacak olursa "Stratejik düşüncenin ilhamını her asırda ya da daha doğrusu tarihin her döneminde olayların yarattığı sorunlarından aldığı gözlemlenmiştir" (Aron 1969: 7). İçinde yaşadığımız etnik veya dini çatışmalar dönemi stratejik düşünce ve tutumda ana eksenin bu şartlardan ilham aldığını veya bu şartları ürettiğini bize göstermektedir. Çatışma öznesi konumundaki kolektif kimlik Wendt'in ifade ettiği gibi özdeşlemeye dayanmaktadır. Toplumsal olarak oluşturulan "Ben" diğer kimlikleri tek bir kimlikte özdeşleştirirken Öteki'nin refahını Benliğinkinin bir parçası olarak tanımak ve "fedakâr olmak" konularında aktörleri teşvik eden nedensel bir güce sahiptir (Wendt 2016: 285). Bu kolektif kimlik parçalanmaları ulusal çıkar kavramını etnik veya mezhebi bir alana taşıyarak devlet-toplum bileşkesini, siyasi birliği bozmakta, şiddet yaygınlaşmaktadır.

Stratejinin arkasındaki gücün (askeri siyasi-hukuki veya ekonomik) dayandığı temel öğe o gücün "Ağırlık Merkezi" dir. Ağırlık Merkezi bir kuvvetin hareket serbestîsini, fizikî gücünü ve mücadele azmini artıran imkân ve kabiliyetler, özellikler ve mekânlardır. Stratejik alanların da ağırlık merkezleri bulunmaktadır (hukuk sistemi, mali sistem, ekonomik sistem, askeri sistem vb.). Operatif olarak "Ağırlık Merkezi, fiziken tahrip etmek, yönetim ve kontrol mekanizmasını bozmak, müttefiklerinden tecrit etmek, lojistik imkân ve kabiliyetlerini sekteye uğratmak, liderliğin mücadele azmini kırmak gibi yöntemlerle ortadan kaldırılabilir veya sınırlandırılabilir." (FM 3.0 Operation). Ulus Devletin ağırlık merkezi siyasal birliktir. Günümüzde stratejik etki bu moral birlikteliğe yönelmiştir (Ay ve Ergün, 2014: 207).

Kolektif kimlik parçalanmaları üzerinden devletin fiziki varlığı başta olmak üzere nesnel çıkarlarına yönelen sürdürülebilir eylem süreci bu haliyle ontolojik olarak siyasi niteliği haizdir. Terörizm ve eylem kipi olan "Terör/şiddet" birileri için ve belirli bir stratejik yöne 
sahip değişik ölçekli siyasi amaçlara yönelik karakter arz etmektedir. Terörizmin belirli bir stratejik tutumla bağlantısı ve siyasi bir etkiyi amaçsallaştırması nedeniyle siyasi bir tercih ürünü ve savaş yöntemi olarak tanımlanması rasyonel gerekçeler içermektedir. Nitekim koalisyonlarca "terörizme" karşı yürütülen hiçbir askerî harekâtın siyasi istikrar sağlamamış ya da sağlayamamış olması da bu tercih ve yöntemle bağlantısını asimetrik olarak göstermiştir. Koalisyon müdahaleleri nihai somut hedefler içermez iken, hedef olarak ortaya konulan olgu ilkesel ve düşünsel karakterdedir. Koalisyonlardaki "kimlik ve çıkar" paradoksu ve uzlaşmazlığı, bakışı askeri ve ekonomik müdahalenin söylem dışı tutulan "siyasi hedefine" yöneltmektedir. Bir askeri müdahale veya savaşa iki temel sorunun cevabı netleştirilmeden girilmez; 1.Savaş nasıl bitirilecektir? 2. Başarı kriteri/kriterleri nelerdir?

Nasıl sona ereceği konusunda fikir birliği olmayan ve ortaya başarı ölçütü koyma noktasında ortak akıl sergileyemeyen, başarı ölçütlerini farklı ulusal veya küresel çıkarların belirlediği koalisyonların tutumu sadece istikrarsızlık üretecek veya istikrarsızlı̆̆ sürdürecektir. Güçlünün stratejisinin kısa sürede (kamuoyunun destek süresi içerisinde) kesin sonuç sağlamayı hedeflemesi gerekirken girişilen harekât sadece yıkım ve "yenişememezlik/belirsizliğin sürdürülmesi" noktasına sürüklenmektedir. Yenişememezlik stratejik başarısızlıktır (Kissinger 2016: 320) ve gerek Afganistan gerekse Irak, Libya ve Suriye müdahale sürecinde bu görmezden geliniyorsa arka planında farklı bir jeopolitik niyet ve dolayım saklıdır. Bu durum iç savaşlara alan açma stratejisi ile bağlantılı simbiyotik çıkar ilişkisi yansıtmaktadır.

\section{Stratejik Tutum}

Kolektif kimlik ve bunun ürettiği çıkarları dizginleme eylemlerinin temel etki vasıtasının yumuşak gücü, siyasi ve askeri yöntemin ise dolaylı tutumu öncelemesi tarihi ve rasyonel bir karaktere sahiptir. Hintli Kautilya (M.Ö. 350-283) M.Ö. IV. Yüzyılda dolaylı stratejik tutumu doktrinleştirmiştir. Kautilya komşuları tarafsızlaştırarak, o ülkede yaşayanların güvenini sarsıp devleti içten çökerterek ve uygun şartlar oluştuğunda fethederek nasıl bir devlet kurulup himaye edileceğini açıklamaktadır. Bu tutum benzer şekilde Sun Tzu tarafindan bilgelik olarak yüceltilmiştir, Çin Han Hanedanlığ 1 ise (M.Ö. 206-220) "beş yem" ile silahlı güç kullanmadan düşmanların aklının nasıl çelineceğini yazmıştır (Kissinger 2016: 214-215, 236-237). Bu yemi yiyen Türk Kavimlerinin başına gelenler Orhun Kitabelerinde yer almaktadır. Bu bilgelik alanı en iyi stratejinin yalnız maddi güç ve şiddete dayanmayan bir strateji olduğunu böylece bu unsurların minimize edilmesini işaret ederken sınırsız şiddet ve kirli savaşların hüküm sürdügü günümüz stratejisinden farklılaşmaktadır.

Yazıya dökülmüş kuramsal stratejik yaklaşımlara M.Ö. IV ve V. yüzyıllarında Asya'da rastlanmakta ise de M.Ö. V. Yy. da strateji alanında temel dikotomi (ikileşim) Homeros'ta da yansıtılmaktadır. Genel hatları ile iki tutum üzerinden stratejik düşüncenin geliştiği gözlenmektedir. Homeros'ta "Bie" ve "Metis" olarak adlandırılmış olan tutumlar özetle şu yapidadır; 
Tablo 1 Stratejik Ana Damarlar

\begin{tabular}{|l|l|}
\hline \multicolumn{1}{|c|}{ Bie } & \multicolumn{1}{c|}{ Metis } \\
\hline Fiziksel alan & Zihinsel alan \\
\hline Güçlü olmak & Zeki ve kurnaz olmak \\
\hline Cesaret & Hayal gücü \\
\hline Düşmanla doğrudan karşıslaşma & Dolaylı tutum, asimetrik durumlar \\
\hline Onuruyla yıkılma & Kandırma ve hilekârlıkla sağ kalma \\
\hline
\end{tabular}

Kaynak: Lawrence Freedman Strateji, s. 94 ten faydalanılmıştır.

Bir noktada "metis" puslu/bulanık mantık alanında hayat bulurken, "bie" çelişmezlik alanının uç sınırında oturmaktadır. "Metis" pragmatik etiği izlerken, "bie" erdemci veya görev etiğini tercih etmektedir. Gerek Arthashastra'nın yazarı Hintli Kautilya gerekse Savaş Sanatı kitabı ile Sun Tzu ile dönemin Asya yaklaşımı "metis" çizgisi izlemiştir.

"Metis" (dolaylı tutum) karşısındakinden daha küçük ve tek bir hamleye dayanan kesin sonuçlu savaşlarda kazanma ihtimali olmayan tarafların tercih ettiği yöntem olarak gelişmiş ise de Asya'da da hile ve kurnazlıklar bilgelik olarak (Zhi) kabul görmüştür. Nitekim Sun Tzu (M.Ö. 500) "Büyük stratejist kandırmacanın ustası olmalıdır. Kuvveti en etkili olacağı zaman kullanmalıdır" önermesi ile dolaylı tutumu destekler, Bütün mücadele aldatmaya dayalıdır" (Tzu, 1910: 6).

Tarih boyunca daha güçlü olanın stratejik tutumu çatışma alanında, halkının ve kaynakların destekleyeceği zaman diliminde kalabilmek maksadıyla kısa sürede kesin sonuca azami/topyekûn güç ile vurma üzerine kurgulanmıştır. İkincil yöntem olarak, çatışmaya sürüklenmemek ve etki alanını genişletmek veya sürekli kılmak için, komşuları veya komşularının komşuları üzerinde metis'e atfedilebilecek siyasi mühendislik eylemleri de meşru görülmüştür.

\section{Dolaylı Tutumdan Küresel İç Savaşa Giden Yol}

Soğuk Savaş Dönemi nükleer stratejilerde caydırıcıllk faktörü ikinci darbelerin rehini olan kentlerle ilgilidir. Bu bir noktada can yakma gücü ve Hava Kuvvetlerinin sahneye çıkışı ile birlikte ortaya konulan hava gücü stratejileri ile bağlantılıdır. Bu bağlamda Trenchard şu açıklamalarda bulunmuştur; "Bir hava kuvvetinin varlığında, düşman ulusu yenilgiye uğratmak için önce silahlı kuvvetleri yenmek şart değildir. Hava gücü ara adımı gereksiz kılabilir. Hava gücü yarattı̆̆ 1 yıııdan ötürü hükümetin işlerliğine ve savaşa devam gücüne zarar verecektir. Halkın baskısı düşmanı teslim olmaya zorlayacaktır. Ancak halka ve yaşam kaynaklarına yönelik yıkım 1949 tarihli Cenevre Sözleşmesi ve 1977 Protokollerinin açık ihlalidir. Konsept hukuka aykırılık üzerine inşa edilmektedir. 19. Yüzyıl Napolyon Savaşlarından sonra yaşanılan büyük tahribatın etkisiyle sivil halkı, yaşam alanları ve kentleri savaş şiddetinden uzak tutmak maksadıyla kodifiye çalışmaları başlatılmıştır. Savaş alanları mümkün oldukça yerleşim yerleri dışında seçilmiştir. Yakın dönemde sivil halkın ve yaşam kaynaklarının korunması konusunda 1949 tarihli Cenevre Sözleşmesi ve 1977 Protokolleri en önemlileridir.

- Halk askeri gerekler dişında göçe tabi tutulamaz. Bu tür önlemler gerekli olduğu takdirde taşınılan yerlerin uygun sağlık ve güvenlik koşullarına sahip olması gerekir. 
- Her halde insanca muamele esastır.

- Sivil halkın varlığını sürdürebilmesi için gerekli gıda maddeleri, tarımsal ürünler, hayvanlar, içme ve sulama sularına karşı eylemde bulunulamaz. Özellikle baraj ve elektrik santralleri gibi tesislere saldırılamaz.

- Tarihsel anıtlara, sanat yapılarına ve ibadet yerlerine karşı düşmanca eylem yapilamaz.

1976 Sözleşmesi çevreye zarar verilmesi suretiyle düşmanla savaşmayı yasaklamaktadır. 1977 tarihli I. Protokol de doğal çevreye ciddi ve sürekli zarar verecek yöntem ve araçların kullanılmaması esasını içermektedir (Md. 55) (Sur 2011: 280).

Konvansiyonel harbin Etki Odaklı yaklaşımında (Effects-based Operation-EBO), düşmanı mağlup etmek için doğrudan siyasî sonuçlar doğuran etkiler yaratılmaya çalışılmaktadır. Modern strateji döneminde gelişmekte olan hava gücüne konsept arayışları çerçevesinde İtalyan Hava Generali Douhet, "düşman ordularını bertaraf etmek için ikmal yollarının ve kaynaklarının imha edilmesi gerektiğini, sivil halkın bombalanmasıyla bir milletin savaşma azminin daha çabuk kırılacağını ve böylelikle zaferin daha kısa sürede kazanılacağını" (Douhet 1983: 126) savunarak modern dönemde kurdeleyi kesmiştir. Douhet'in yorumlarından birçoğuna katılan Amerikalı General Mitchell, hava kuvvetlerinin kullanılmasındaki öncelikler ve düşmanın ağırlık merkezleri konularında görüşler ortaya koymuş, ulaşım, endüstri ve insanların savaşma azminin düşmanın ağırlık merkezlerini oluşturduğunu belirterek hava kuvvetlerinin öncelikli olarak düşman halkının savaşma azmini yok edecek şekilde kullanılması gerektiğini söylemiştir.

I. Körfez Savaşı Harekât Konseptine etkisi olduğu ifade edilen Warden, bütün ülkelerin ve stratejik unsurların sistem yaklaşımı ile analiz edilmesi gerektiğini ortaya koyarak, bu maksatla iç içe geçmiş beş halkadan oluşan bir model geliştirmiş̧ir. Modelde merkezden dışarıya doğru ve azalan öneme göre sırayla liderlik, önemli organlar, altyapı, nüfus ve askerî kuvvetler yer almaktadır. Modele göre stratejik planlar her zaman öncelikle liderliği hedef almalıdır. Eğer liderliğin hedef olarak alınması mümkün olmuyorsa, diğer halkalar arasından hedef seçimi yaparken düşman liderlerinin zihnini etkileyecek olanlar üzerinde odaklanılmalıdır (Warden 1993: 4). Sadece askeri yapı değil, sivil halk ve halkın yaşamını sürdürebilmesinde ihtiyaç duyacağı kaynaklar bu halkanın içerisindedir.

Nizami Harpte sivil halk ve yaşamsal alanlara yöneltilen etki son yüzyılda en büyük uygulamayı Japonlar üzerinde göstermiş, açıkça savaş ve insanlık suçu tekraren işlenmiştir. Esasen sivil kayıpların savaşın sonunu belirlemedeki rolü, yakın tarihte, sivillerin kitleler halinde ölümüne neden olan Hiroşima ve Nagazaki'ye atılan atom bombalarında, Tokyo halkı üzerine atılan yangın bombalarında kendisini göstermiştir. Bu eylemleri ile ABD art arda sivil katliamlar yapmasına rağmen uluslararası ceza takibatına uğramamıştır. Aynı şekilde müttefik hava kuvvetlerinin halı tipi bombardımanları kentlerde yaşayan sivil Almanları vurmuş, Alman füze ve uçakları ise bombaladığı şehirlerde binlerce sivilin ölmesine neden olmuştur (keza Japonya). Örnekleri çoğaltmak mümkündür. Nürnberg ve Tokyo Ceza Mahkemelerinde sadece mağluplar yargılanmıştır. Sömürgeleştirme ve dekolonizasyon dönemlerinden bu yana yerli halkın/sivillerin kıyımı Batı devletleri açısından alışılageldik bir durumdur.

Yeni yüzyılda hükümetin politik direncini kırmak için yaşamsal alana yönelik etki harekâtları, Kosova, Sırbistan, Irak, Afganistan ve Libya'da sergilenmiş ve önleyici vuruş, önleyici meşru müdafaa gibi doktriner ve hukuki açıklamalar getirilmiştir. İstikrar 
harekâtının devlet terörüne dönüşümünün bir örneği ise Suriye ve Myanmar'da sergilenmektedir.

Terörizm, silahlı kuvvetlerin ziyade direnme gücünü ortadan kaldırmadan ziyade, cesaret kırıcı bir korku yaratmak suretiyle insanların hükümete destek olma duygusunu tahrip ederek hükümetin arkasında olmalarını engelleme amaciyla konvansiyonel harbin dolaylı tutumu ile bu noktada birleşmiştir. Nizami savaşta sivillerin öldürmesi savaşın arıîi bir neticesi olması gerekirken siviller hedef alınmaya başlamıştır. Teröristler için ise sivilleri öldürmek zaten bir gerekliliktir ve bu nedenle terörizm öncelikle sivilleri hedef almaktadır (Henderson 2001: 6).

Bask1 ve tehdit ile halkı korkutmak ve y1ldırmak suretiyle siyasi bir sonucu hedefleyen eylemler terör olarak tanımlanıyor ise (ki öyledir), konvansiyonel harbin Etki Odaklı yaklaşımı $(\mathrm{EOH})$ terörize olmuş konvansiyonel bir savaş biçimini yansıtmaktadır. Düşmanı mağlup etmek için silahlı kuvvetleri yıpratmadan doğrudan siyasî sonuçlar doğuran etkilerin (sivil halk ve yararlandığı yaşamsal kaynaklar dâhil) yaratılması hedeflenmektedir. Terör eylemlerinin yeni versiyonunda sabit mevzi türevi hendek çatışmaları veya DAEŞ işgallerinde görüldüğü üzere meskûn mahallerin işgali ve savunulması terör örgütlerinin konvansiyonel tutumlar takındığını göstermektedir. Terörize konvansiyonel savaş ve konvansiyonel hedefleri/taktikleri olan terör eylemleri, hibrit savaşların doğumunu yansitmaktadir.

\section{A. 21.Yüzyılıda Başat Tutum-Hibrit Stratejiler}

Asimetrik Küreselleşme, soğuk savaş döneminden sonra barış ikliminin hâkim olması beklenen uluslararası ve yerel atmosferi, zengine daha fazla gönenç fakire daha fazla yük getiren sera etkisiyle 1sitmış, yerküre adaletsizlik ve eşitsizliğin artan ivmesi ile silahlı çatışmalar ve asimetrik savaşlar evrenine dönüşmeye başlamıştır. Manzara 2011 yılında Almanya Başbakanı Merkel tarafindan, Orta Doğu ve Kuzey Afrika'da "siyasi çalkantının bölgenin jeopolitik tektoniğini harekete geçirdiği”" (Ergün 2015: 419) ifadesi ile netlik kazanmaktadır.

Post modern etkiyle yapılanan post modern jeopolitik tasarı toplumların fay hatları üzerine inşa edilmekte ayrılık ve farklılıklar üzerinden kurgu ve eylem üretmektedir. Siyasi birliği ve dış etkilere karşı bağışıklık sistemleri zayıflayan ülkeler bu sarsıntılarla parçalanmakta, insanlar katledilmektedir (Ergün 2015: 420). Critchley böylece post-metafizik olduğu söylenen seküler bir çağdan, siyasi eylemin doğrudan doğruya metafizik çatışmadan doğuyor gibi göründüğü yeni bir duruma bir şekilde geçildiğini öne sürümektedir. Bu durumu ölümcül sonuçları olan üçlü iç içe geçişle ifade etmektedir: "Siyaset, din ve tepe noktasında şiddet" (Critchley 2013: 16).

Vekâlet savaşları (Proxy Wars) geçmiş dönemlerde nükleer silaha sahip büyük güçlerin konvansiyonel hedeflere ulaşmada bağlantılı ülkelerin silahlı kuvvetlerini (Ordu) kullanmaları ile ortaya çıkmış iken günümüzde yerini ülkelerdeki sosyal grupların silahlandırılarak kullanılmasına veya desteklenmesine bırakmıştır (Sosyal Güçler). Savaşın temel aktörü olan konvansiyonel ordu bazı bölgelerde destek unsuruna dönüşmüş (Kırım, Ukrayna, Suriye) iken başka coğrafyada gayri nizami kuvvetlere alan açarak arka plana çekilmektedir (Irak, Afganistan, Libya). Stratejik tutum doğrudan güç kullanımının bir süre sonra dolaylı kullanıma yerini bırakmaktadır. 
Savaşlar; konvansiyonel güçlerin resimetrik $^{2}$ olarak kullanıldığı, topyekûn kavramının dönüşüme uğradığı, farklı aktör ve araçların girişi ile melezleşmiş/hibritleşmiştir. Hibrit Savaşlar, kavramsal olarak; siyasi veya jeopolitik maksadın tahakkukuna hizmet eden, her tür şiddet unsuru/vasıtasının kullanıldığı örtülü stratejiler içeren torba kavram niteliğindedir. Bu savaş türü NATO’nun Münih Konferansı öncesi ve sonrasında yapılan açıklamalarda Kırım ve Ukrayna gelişmelerine atfen "Batılı Devletlerin istikrarını süratle bozabilecek tehditler içeren bir savaş türü. Partizan taktiklerinden enerji-politik tedbirlere ve siber saldırılara uzanan geniş bir tayfi kapsamakta, devlet ve devlet dışı aktörler kombine edilerek kullanılmaktadır" (Michael 2015) ifadesi ile betimlenmektedir. Esasen yeni keşfedilen bir savaş türü değildir. Batılı ülkelerin belirli alanlarda ve sınırlılıkta örtülü olarak uyguladığ ancak Ruslar'ın uygulaması ile Batı çıkarları etkilendiğinden müstehcenleştirilmiş ve alenileştirilmiştir. Uygulamada ülkelerin konvansiyonel savaşçıları ülke tanımlayıcı işaret ve alametleri taşımamakta, gerilla veya partizan savaş düzenine geçebilmekte, terör örgütleri ve kriminal gruplar, siber saldırılar, dezenformasyon, propaganda, iktisadi ve finansal vasitalar, enerji kartları, medya ve internet kullanılmaktadır (Sputnik 2013, Zeit 2015). Topyekûn kavramının post modern versiyonu ortaya çıkmaktadır. Hibrit savaş saha olarak kentsel alanları tercih etmektedir. Savaşın bir nesnesi haline getirilen kent, insanı koruma kalkanı oluşturduğu gibi her savaşın nihai hedefini teşkil eden siyasi sonucu hızlandırıcı bir etkenkaynak olarak da işlev görmektedir.

Savaşın doğasına ait her şey hibritleşmiştir/melezleşmiştir. Terörizm ile gerilla savaşının farklılaştı̆g en önemli nokta ahlaki yaklaşımdır. Gerilla pratisyenlerinden Che Guevara eylemlerini bir sürü masum insanın canına kıyan ve zararlı bir araç olan terörizmden net bir şekilde ayırmayı çok önemli bulmaktadır. "Sabotaja halkın bir bölümünü felç edecek, yani insanları işsiz bırakacak şekilde üretim araçlarını kullanılmaz hale getirmek için başvurulmamasını" öğütler. "Askerlik ödevlerini yerine getirerek ya da getirdiklerini sanarak çarpışan askerlere karşı mümkün olan en üst düzey merhamet gösterilmelidir." Guevara gayri nizami harpte gerilla savaşının ahlaki yönünü net bir şekilde ortaya koyarak, yöre halkının geleneklerine ve kurallarına karşı büyük bir saygı ister (Guevara 2011: 20-24). Bu çerçeveden bakıldığında terörist ahlaksız gerilladır. Bu arada ABD, İngiliz, Fransız özel askeri şirketleri mensuplarının yaptığı kıyımlar şirket savaşçılarının ya da "özelleştirilmiş savaşın” da ahlaki sınır tanımadığını gözler önüne sermektedir. Paralı askerlerin dönüşü” Yeni Orta Çağ" metaforunu haklı çıkarmaktadır. Savaş etiği melezleşmiştir.

Savaş tekrar bir iş kolu ve geçim sahası haline gelmiştir. İç savaş ekonomilerinin OECD dünyasının barış ekonomisiyle birbirine bağlanması büyük önem taşımakta ve bir şekilde de bağlantı sağlanmaktadır. DAEŞ/IŞi̇' in mali finansmanının ancak kaynakların bombalanması suretiyle engellenmeye çalışılması bunu doğrulamaktadır. Doğal kaynakların ve illegal malların ticareti, bunun yanı sıra kuzeyin yardımlarının ticareti, iç savaşların neden bu kadar uzun sürdüğüne bir açıklama getirmektedir (Somali, Kongo, Afganistan) (Münkler 2003).

Maliyet, yenilme riski (nitekim ABD II. Dünya savaşından sonra bizzat yürüttüğü beş konvansiyonel savaşta da başarısız olmuştur. Üçünde - Vietnam, Irak ve Afganistan- "yolun daha başındayken" tek taraflı olarak geri çekilmiştir (Kissinger 2016: 305,315). Savaşın yükselen maliyeti ve saldırgan duruma düşmeme isteği, terörizmi, hedef devletten istenilen siyasi çıktıyı alamaya zorlayan politik bir araç haline getirmiştir. Terörizmin bu denli etkili

\footnotetext{
${ }^{2}$ Asimetriye mukabele. Özel Kuvvetler, jandarma, korucu güçleri gibi paramiliter iç güvenlik organizasyonları şeklinde teşkilatlanmalar ve Özel Şirket askerleri.,
} 
olmasının arka planında yatan gerçek "Devlet Destekli Terörizm" saptamasında yatmakta ve stratejik bir tutumu işaret etmektedir. Dolayısıyla sosyal bilimler disiplinlerinden ziyade strateji ve güvenlik disiplinin doğrudan inceleme alanıdır.

M. S. Erol bir incelemesinde, mevcut birçok tanımın (100 ün üstünde) ortak yönüne dayanarak terörü; sivillerin hedef alındığı, genellikle şiddet ve dehşet olgularının birleștiği, siyasal içerikli ve kurulu bir düzene-sisteme yönelik amaçlı eyleme verilen ad şeklinde vektörleştirmektedir (Erol 2008: 76-79). Tanımlama tekniğinin gerektirdiği soyutlamalar sonucu ortaya çıkan bu vektör stratejik eylemin gerçek profilini silikleştirme sakıncası taşımaktadır. Her vektör gibi derinlik ve zaman boyutunun anlamlaştırılmasından ve bilişsellik boyutundan oluşan sıkıntıları mevcuttur. Siyasi amacın arkasındaki niyet, son safhada ortaya çıkacak resmin tasviridir. Niyet her safhadaki amaçların, amaç/maksat ise safha hedeflerinin belirleyicisidir.

Saldırı tanımının üzerinde uzlaşamayan uluslararası hukuk tartışmalarının bunun viral ve müstehcen modeli terörizmi tanımlama sorunu üzerinde uzlaşması beklenmemelidir. Neticede ulusal düzeydeki tanımlamalar iç siyasi ve stratejik zeminde anlamlı ve gereklidir. $\mathrm{Bu}$ durumda günümüzde savaşı ve terörizmi; hasmın ulaşmak istediği nihai jeopolitik resim odakl1, siyasi bir amaçla, devlet otoritesine veya devletlere karşı, devletin koruma güçlerinin, sivillerin, insani yaşam kaynaklarının hedef alındığı etki odaklı hareketler toplamı olarak bütünleştirebilir- hibritleştirebiliriz (melezleştirebiliriz).

\section{B. Rehine Stratejileri}

Şehzade ve prenslerin hasım ülkelere sığınması veya kaçırılması yoluyla rehine durumuna düşürülmesi, bir devletin siyasi uygulamalarına etkili olma yöntemi modern devlette değişik ölçeklerde ve kişiler üzerinden devam edegelmiştir. Modern dönemde ülke üzerinde değişik emelleri olan hegemonik güçlerin muhalif liderlere ve kanaat önderlerine sığınma hakkı tanıması veya oturma izni vermesi aynı kapıya çıkmaktadır.

Rehine stratejilerinin ulaştı̆g en uç boyut sivil halkın kitlesel rehine haline dönüştürülmesidir. Gerek sivil halkı ve yaşamsal kaynakları hedef alan konvansiyonel EOH gerekse "karşılıklı garantili yıkım" kavramı üzerine inşa edilmiş olan nükleer stratejide ortak olan özellik kentlerde yaşayan sivil halkın hedef alınarak rehineye dönüştürülmesidir. Soğuk Savaş döneminde misilleme rolü verilen nükleer silah kullanımı, G.W Bush döneminde (karş11ıklı garantili yıkım stratejisi) önleyici nükleer savaş doktrinine dönüştürmüştür ilk saldırı konumuna geçirilmiştir. Bu (Roberts, 2016: 18). Kentselleşen ve yaygınlaşan terör nükleer tehdidin yanısıra mega kentler başta olmak üzere meskûn mahallerde yaşayan nüfusu siyasi rehine durumuna sürüklemiştir. Ortaya çıkan resimde kent insanları Baudrillard'ın betimlemesiyle "terörizmin ve nükleer caydırıcılığın potansiyel rehineleridir" (Baudrillard 2011: 45-47). Can yakma potansiyeli diplomatik bir şantajdır. Yarger'in ifadesi ile "can yakma gücü bir pazarlık gücüdür. Bunu sömürmek diplomasidir -kötücül bir diplomasidir, ama diplomasidir" Can yakmak için nükleer silaha ihtiyaç yoktur (Freedman 2015: 296). Caydırma ve zorlama stratejilerinin buluştuğu stratejik bir tutum ortaya çıkmıştır.

\section{Holistik Operasyonlar}

Türk Silahlı Kuvvetleri komuta yapısını ve moral değerlerini hedef alan, çeşitli isimlerle anılan yargı operasyonları stratejik sonuçlar yaratmış, TSK'ni siyasi ve askeri denklemden düşürmüş, kurumsal hafızasına büyük darbe indirmiştir. Hükümet/Lider kadrosuna yönelik ve ciddi istihbarat alt tabanı içeren 17/25 Aralık operasyonları gibi dolaylı şiddet içeren ve 
yabanc1 sert güç müdahalesine gerek kalmadan ülkede siyasi sonuç almaya yönelik bu "dolaylı tutumlar"’n bir savaş türü ve stratejisi bağlamında izi sürülmeksizin anlaşılması güçtür. Bu durumu açıklayan bir terim Holistik Operasyonlar adı altında ortaya konulabilir.

Holistik çift anlam taşıyan bir terimdir. İlk anlamı eskiden beri bilinen bir metot, bir şifa yöntemini ifade etmektedir. Bedensel hastalıklar ancak "canlının kendi doğasındaki iyileşme potansiyelini harekete geçirerek beden tarafından tedavi edilebilir. Bünyede rahatsızlık yaratan "yerel" organlar olarak bünyenin diğer vasitalarınca sisteme uygun hale getirilecektir. Aynı kültür havzasından gelmiş yerli ve milli pasaportları ile aynı bünyeye ait görünen insanların kendi ülkesi, sistemi ve insanlarına karşı kullanılması holistik bir eylemdir. Holistik süreçte stratejist uzun vadeli çıkarlar için, hızlı ve kısa vadeli çözümleri reddetmelidir (Yarger: 73-75).

Sistemin içine yerleşen terör hücreleri Baudrillard'ın ifadesiyle "viral uyku hücreleri" aktive edilince düşmanca hareketlere başlarlar. İçeride bir dış oluştururlar. Sisteme dışsal kuvvetler olarak saldırırlar" (Baudrillard 2002b: 20, 98). Ötekinin teröründen çok daha tehlikelisi aynının terörü, sisteme içkin terördür, ona karşı savunma aracımız yoktur (Chul 2016: 100).

Politik parçalanma ve eşzamanlı olarak çoğullaşma, Türkiye ve içinde bulunduğu heterojen bölgenin temel sorunu haline gelmiştir. Bu bağlamda çevreleme, jeokültürel alanda düşünce veya değerlerin asimetrik klonlanması yoluyla yumuşak güç kullanılarak icra edilmekte düşmanın ve düşmanca davranışı tanımlayan kurallara uygun doktrinlerin geliştirilmesi güçleşmektedir. Baudrillard'ın betimlemesiyle "bu şiddet viral bulaşma, zincirleme reaksiyon ve tüm bağışıklıkların yok edilmesi yoluyla yayılıyor" (Baudrillard 2002b: 54). Ezcümle siyasal HIV terörü ile karşı karşıyayız. Bu durumda Olağanüstü Hal yönetimini olağan yönetim tekniği haline getirmektedir.

Holistik eylemin Orta Doğu başta olmak üzere kriz sahalarında gerçekleştirilebilmesinde en önemli araçlarını ışı hızını düşüren ticari medya ve bilgi kirliliği yaratan güdümlü STK'lar (Sivil Toplum Kuruluşları) oluşturmaktadır. Işık hızının düşürülmesi metaforu olayın ve failin eşleştirilmesinde, teşhis ve tedbirin alınmasında, kamuoyunun oluşumunda refleksif zaman aralığının uzamasını resmetmektedir. STK'lar, Hükümet Destekli Kalkınma ve Yardım kuruluşları yumuşak güç uygulamaları ile algı, imaj ve itibar yönetimi üzerine kurulu Kamu Diplomasisinin psy-ops" faaliyetlerinin temel vasitalarından biri haline gelmiştir (Shank 2014). Nitekim ABD yumuşak güç aktörlerinden birisi olan USAID (ABD Uluslararası Kalkınma Ajansı)'in "yabanc1 ülkelerde politik figürlere" milyonlarca dolar ödeme yapan büyük bir rüşvet fonunun varlığı Kongre araştırması sonucunda ortaya çıkarılmıştır (Turley 2014).

Devletin bir başka devlette desteklediği holistik unsurlar vasıtasıyla kazanmaya çalıştığı siyasal ve hatta askeri sonuçlar bizi yine terörizm kavramına götürmektedir. Zorbalığın olmaması nasıl "güç" yokluğuna tekabül etmiyor ise görünürde fiziksel şiddetin olmaması da olmayacağının kanıtı değildir. Holistik kavramına eleştirel yaklaşarak arka planına baktığımızda, asimetrik bir faaliyet türü çağrısı algılamak zor değildir. Bünyedeki rahatsızlık bünyesel güçlerle senkronize bir şekilde tedavi (!) edilmektedir. 15 Temmuz 2016 FETÖ darbe girişimi ile askeri organ tedavi edilirken (Orta Doğu'da rahatsız edici etkili bir aktör olmaktan büyük ölçüde çıkmıştır), siyasi organ/liderlik tedavi edilememiş (daha güçlenmiş) rahatsızlıklarının şiddetini artırmıştır. 


\section{Küresel İç Savaş}

Başta ABD olmak üzere üstünlük politikalarının yarattığı vekâlet savaşları, rejim değişiklikleri, tarımın 2001 yılından itibaren rekabete açılması sonucu topraklarından kopmaya başlayan milyarlarca köylünün yersiz yurtsuzlaşması, iklim değişikliği nedeniyle göç etmek zorunda kalan insanların oluşturduğu vektörel uzamlar son tahlilde Parenti'nin ifadesi ile "Felaketlerin Kesiştiği" bir yüzyıl1 işaret etmektedir. Küreselleşmenin başat aktörleri olan Batılı Güçlerin neden olduğu adaletsizlik, insan ve mal kaçakçıllk sektörünün gelişimi, ülkelerinde rüşvete ve yolsuzluğa boğulmuş yöneticilerin aczi ve uygulamak zorunda bırakıldıkları Neoliberal eşitsizlik politikaları, gelişmekte olan ülkeler için Parenti'nin ortaya attığı "Tehdit Çarpanı"nı oluşturmaktadır. Bu çarpan etkisi Başarısız Devlet sayısı ile birlikte azalan kaynaklar için de devlet içi ve devletlerarası çatışmaları artıracaktır (Parenti 2011: 17). Duruma asimetrik küreselleşme penceresinden bakan sosyal bilimciler ise 1990'lı yıllardan itibaren "Yeni Kolonizasyon"un başladığını ifade etmektedirler (Mayo, 2013).

Köni’ye göre Batılı güçlerce büyük göçleri önlemek için geliştirilen mekanizma askeri güç kullanımı ötesine geçmemektedir. Göçmen dalgalarının çevrelenmesi ve dışlanması, aç şehir isyancılarının bastırılması (Köni 2016: 22) mücadele eksenini oluşturmaktadır. Aynı çerçevede Schneider AB'nde Avrupa'ya yönelik göçmen akınlarının önlenmesinde de OHAL politikaları uygulanmak suretiyle göçmenlerin düşman olarak görüldüğü bir mücadele stratejisinin ortaya çıktığını öne sürmektedir (Schneider 2008). Köni Amerikan Askeri El Kitaplarında bu tür düzensiz göç hareketlerine karşı yürütülen savaş modeline "Teröre Karşı Savaş" adı verilmekle birlikte, bu savaşında genel olarak terörist güçlerin yanında yer alan sivil halka karşı sürdürüldügüne dikkat çekmektedir. Şehirlere yansıyan terör karşısında başarılı olunamayıp kayıplar artıca, Latin Amerika'da daha önce kullanıldığı şekilde halk içinden yönetime sadık paramiliter güçler yaratılacaktır.

1960'l1 yillarda ilk olarak H. Arendt'in "Devrim Üzerine" ve C. Schimitt'in "Partizan Teorisi" kitaplarında kullandığı "Küresel İç Savaş" terimlerinden hareke eden Agamben yeni dünya düzeninin ABD tarafından sonu gelmeyen "Küresel İç Savaş" üzerine kurgulandığını öne sürmektedir. Devlet/Terörizm ikilemi içerisine sıkıştırılan ve indirgenen Dünya Politikası Olağanüstü Hal (OHAL) uygulamasını normal yönetim tekniği haline getirmiştir. OHAL ve Küresel İç Savaş paradigmik olarak stratejik bir bağlantı içerisindedir. Savaş hukukunun bile geçerli olmadığı Guantanamo gibi toplama kamplarında sergilenen tutum ile ABD küresel düzeyde bir OHAL durumunu dikte etmektedir (Agamben 2008: 14). Küresel güçler düzeni değil düzensizliği yönetmek istemektedir.

Terör, bir devletin diğer devlete ya da devletlere karşı, sivil halk/sosyal güçler ${ }^{3}$ üzerinden, yürüttüğü dolaylı bir stratejik tutuma dönüşmüştür. Devlet dışı silahlı grupları desteklemek, himaye etmek (sponsorluk) ya da tolerans göstermek suretiyle siyasi sonuçlara yönelmektedir. Terör eylemlerinin topolojisini çıkaran Hosbawm 1980'lı yıllardan itibaren devlet himayeli terörizmin bir devletin diğer devlete karşı uyguladığı bir savaş yöntemi olarak belirdiğine (Hosbawm 2008: 137-138) dikkat çekmektedir. Benzer tespitleri Cline ve

\footnotetext{
${ }^{3}$ Sosyal Güç, bir başkasının davranış ve duygularını, belirli amaçlarla etkileme kapasite ve yeteneğidir. Sosyal gücün uygulayıcısı bireysel seviyede bir şahıs, mikro seviyede bir baba, mezo seviyede bir banka yöneticisi, global seviyede bir Başkan'dir. Güç uygulanan/kurban bireyler topluluğu ve hatta millet olabilir. Donley, R.E.,, Winter, D.G.: Measuring the motives of public officials at a distance: An exploratory study of American presidents. Behavioral Science, 1970, 15, 227-236.dan aktaran Erich H. Witte ,Theorien Zur Sozialen Macht, Sozialpsychologie, Psychologisches Institut I der Universität Hamburg, HAFOS, 2001 NR. 30 ss: 7-12.
} 
Alexander ve Kedikli'de de görmek mümkündür (Kedikli 2013: 132). Nitekim Hosbawm bu tırmanışla ilgili olarak verdiği örneklerde “1970”lerden önceki Sri Lanka 1lımlı sosyalist bir yol tutturmuş, Asya standartlarına göre Latin Amerika'da ki Uruguay ve Kosta Rika gibi ender rastlanan bir uygarlık ülkesiydi. Bugün ise baştan aşağı kana bulanmış durumdadır" (Hosbawm 2008: 129).

Siyasi birlikteliği parçalanmış ve politik paranoya içerisindeki toplumların fay hatlarının tetiklenmesi yoluyla çıkacak iç silahlı çatışmanın uluslararası güçlerin askeri ya da politik müdahaleleri ile uluslararasılaştığ 1 ve jeopolitik şekillendirme vasıtası olarak kullanıldığ bu dönemin sonucu ya küresel çöküş ya da küresel güç dengesinin yeniden oluşması suretiyle son bulacağı düşünülmektedir.

Küresel resmi anlamaya çalışan Marischka gözlemini şu şekilde betimlemektedir:

"Küresel bir savaşa doğru mu gidiyoruz? Tam değil: Illan edilmiş bir savaş yok ama sayısız çatışma bölgesi salgın gibi yaylliyor. Ufukta birleşik savaş cepheleri değil, hiçbir genel stratejik vizyonda birleşmeyen parçalı mikro-çatışmalar ve tekinsiz ittifaklar var. Bunu tanımlayan terim "dünya savaşı”" değil. Buna parçalı küresel iç savaş diyorum. Ve parçalar birleşmiyor, çünkü savaş her yerde” (Marischka 2008).

\section{Kentleşme ve Kentleşen Terör}

Parasal-meta değeri düşük olsa da çiftçisinin yalın hayatını sürdürmeye yetecek ölçekteki, düşük verimli araziler başta çok uluslu agro-businness ler (şirket tarımcılı̆̆ı), maden ve enerji şirketleri tarafindan yutulmaktadır. 2001 yılında Dünya Ticaret Örgütünün dayatmasıyla ulusal koruma ve teşvikler kaldırılarak genel rekabet kurallarına tabi kılınan tarım ve yine tarım arazilerinin yabancılara satışa sunulması. Amin'in tespitlerine göre birkaç on milyon çiftçi ve yeşil devrim ${ }^{4}$ nimetlerini kullanan tarımsal kapitalizmin şirketlerini (yoksul köylü tarımı-ister istemez organik- karşılaştırıldığında verimlilik oranı 1'e 200) başat konuma sokacak, rekabete dayanamayan yoksul çiftçi köylüler (3 milyar) topraklarını terk ederek şehirlere göçecektir. Bu önümüzdeki on yıllar içerisinde en az 3 milyar insanın daha göçebe durumuna düşmesi anlamına gelmektedir (Amin 2016: 31-33). "Batılıların bu gelişmeler karşısında uyguladıkları strateji askeri bir stratejiyse, dünyadaki üç milyar fakirleştirilmiş ve ezilmiş insana karşı sonsuza kadar "Teröre Karş1 Savaş" politikası mı izlenecektir?". Göçmenler ve yabancıların çevrelediği şehirler potansiyel olarak kaos unsurları haline gelmektedir.

Göçlerin ortaya çıkardığı "Gecekondulaşma" zamanımızın en önemli jeopolitik olaylarından biri olarak nitelendirilmektedir (Davis, 2004). Gecekondularda yaşayanların yerleşik kentli nüfusun çoğunluğunu oluşturacağı dünyanın gelişen ve azgelişmiş ülkelerinde ortaya çıkacak olan sonuçlar yeni "yönetişim" kavramları üretilmesi ile geçiştirilecek gibi görünmemektedir. Devlet denetimi dışında, yarı yarıya yasa dışı koşullarda, minimal örgütlenme biçimleri ihtiyacı içinde yaşayan bir nüfusun hızla büyümesine tanık olunmaktadır.

\footnotetext{
${ }^{4}$ Sentetik gübre, melez tohumlar, ilaçlama ve modern makine ve teçhizat kullanılarak yapılan tarım. 1960'lı yıllarda başlayan Yeşil Devrim ve onu takip eden GDO'lu tohumlar devriminin başrolünde Rockefeller ailesi bulunmaktadır. Daha sonra Ford Vakfi bu sürece dâhil olmuştur. ( F.W. Engdahl, 2013:105). Bugün ucuzlayan terörizm odaklı şehir savaşlarının gözde silahı EYP (el yapımı patlayıcılar)'lerin ana maddesi kimyasal gübre olan Amonyum Nitrat, II. Dünya Savaşı sonunda patlayıcı üretiminde kullanılan Nitrojen fazlasının gübre şeklindeki nitrojene dönüştürülmesi ile dünyaya yayılmıştır.
} 
Dünyada 2015 yılı itibarıyla 7.324.782 kişi yaşamaktadır (UNDP, 2015). 65 milyon kişiye ulaşan nüfusla mülteciler 2015 yılı sonu itibarıyla dünyanın beşinci büyük devleti, 21nci büyük milleti durumundadır. Bu nüfusun yarısı çocuktur. BM Gıda ve Tarım Organizasyonu, bugün dünyada her 9 kişiden birinin gece aç uyuduğunu belirtmektedir (FAO, 2015).

2010-2015 yılları arasında kentleşen nüfus gelişmiş ülkelerde \%0,3 artarken bu artış Afrika'da \%2,5, Asya'da \%1,5 olmuştur. 1950 y1lından bugüne kadar uzanan çizgide Afrika'da kentlerde yaşayan nüfus 33 milyondan 373 milyonun üzerine sıçramıştır. $\mathrm{Bu}$ sayılar Batılı finans iktidarlarının zayıf ülkelerde gerçekleştirdikleri "arazi soygunu" (Landgrabbing) nedeniyle de hızla yükselmektedir. 2008 Finansal krizini takip eden dönemde, sadece Ekim 2008 ve Haziran 2009 arasında Dünya genelinde en az 47 milyon hektar toprak, satın alma ile küresel finans şirketleri ve firmaların kontrolüne girmiştir. $\mathrm{Bu}$ miktar İsveç'in yüzölçümüne ve bununla birlikte Avrupa Birliğinin tarıma elverişli topraklarının çeyreği kadar bir kesime eşittir.Bu toprakların da yaklaşık \%75'i Afrika da yer almaktadır ve bu durum kıtanın en az 23 ülkesinde cereyan etmektedir (Bernau, 2012). Oakland Enstitüsü, "Wall Street Kurtları"nın "önümüzdeki iki y1l içinde (2015-2017) 400 milyon hektar tarım arazisini satın almak için hazırlık yaptıklarını" (Oakland Ens. 2014) öne sürmektedir.

Yersiz yurtsuzlaştırılarak şehir varoşlarında sadaka ekonomisiyle hayatta tutulan bir zamanların üretici kitleleri göçmenler, çaresiz stratejilerin sürtünmesini yaşayan hükümetlere yük olduğu kadar tehdit teşkil etmeye başlamış, kentleşen savaşın insan kaynağını oluşturmuştur.

Kentleşen terörizmin özelliklerini şu şekilde sıralamak mümkündür;

- Halk desteği elzem değildir.

- Üs bölgesi ihtiyac1 yoktur

- Merkezi kontrol gerektirmez

- Lojistik ve iletişim sorunu yoktur

- "Beton ormanında" fark edilmek daha zordur

- Hedef kitle sıkıntısı yoktur, sansasyonel niteliği ve eylemin manşet değeri yüksek, maliyeti düşüktür.

- Halk potansiyel rehinedir.

- Halk kolay kitlesel hedef olmasının yanısıra canlı kalkan olarak kullanılabilmektedir.

\section{Sonuç}

Terörizm tanımları sivillerin hedef alındığı, genellikle şiddet ve dehşet olgularının birleştiği, siyasal içerikli ve kurulu bir düzene/sisteme yönelik amaçlı eyleme olarak evrilirken, konvansiyonel bir savaşın nihai amacında da siyasi bir hedefin gerçekleştirilmesi için şiddet kullanımı yer almaktadır. Ancak meşruiyeti egemen bir devletin kendini koruma zorunluluğu ve eylemlerin savaş hukukuna uyması ile sınırlıdır. Yaşanan olaylarda büyük güçler için bu sınırın sadece söylemsel olarak mevcudiyetini koruduğu gözlemlenmektedir. Konvansiyonel savaş günümüzde terörize olmuştur.

Vekâlet savaşlarının (Proxy Wars) incelenmesinde geçmiş dönemlerde nükleer silaha sahip büyük güçlerin birbirleri ile doğrudan çatışmaya girmeksizin kullandığı vekil/yerel ordular günümüzde yerini karşı ülkelerdeki sosyal grupların silahlandırılarak kullanımına (sosyal güçlerin) ya da devlet dışı silahlı gruplara bırakmıştır. Terör örgütleri Gayri Nizami Harpte 
yerelgerilla unsurunun yerini almıştır. Temel aktör olan ordu destek unsuruna dönüşmüştür (Kırım, Ukrayna, Suriye). Dolayısıyla konvansiyonel savaşın terörizmi içselleştirdiği, terör örgütlerinin de konvansiyonel hedeflere yönelik vekâlet savaşlarını üstlendiği karmaşık bir dönemde yaşıyoruz. Bu demektir ki "teröre karşı daha fazla demokrasi" türü popülist söylemler gerçekçi bir yaklaşım değildir. Nitekim George Friedman ${ }^{5}$, 1990'lı y1llarda ABD’nin çeşitli ülkelere saldırılarının amacının "bölgede güçlü olmaya niyetlenenleri kaosa sürüklemek olduğunu, Amerikalıların seçtiği zaman ve yerde, bölgesel ve iç tehditlerle uğraşmasına sebep olduğunu" ifade etmektedir. Aynı şekilde Irak'ın işgaliyle Suudi petrol yataklarına birkaç saatlik mesafeye Amerikan Birliklerinin yerleştirildiğini, bu surette Suudilerin gözünün korkutulmasının yanı sıra, ABD işgalinin bölgedeki komşuları, Kuveyt, Türkiye, Ürdün, Suriye, İran olan en stratejik ülkenin (Irak) kontrolünü kazandırdığını değerlendirmektedir (Friedman 2011: 23).

$\mathrm{Bu}$ bağlamda İttifaklar sistemi bütünselliğini yitirmiş, bölgesel çerçevede dama tahtası örüntüsüne dönüşmüştür. $\mathrm{Bu}$ durumu Nosthoff ve Maschewski "Ufukta birleşik savaş cepheleri değil, hiçbir genel stratejik vizyonda birleşmeyen parçalı mikro-çatışmalar ve güvenilmez ittifaklar var. Bunu tanımlayan terim "dünya savaşı" değil. Buna parçalı küresel iç savaş diyorum. Ve parçalar birleşmiyor, çünkü savaş her yerde" ifadesi ile betimlemektedir. Sürekli Kriz stratejik bir tutum olarak devlet dış politikalarını terör ve güvenlik ikilisine indirgemiştir.

Her ölçekte arzu edilen siyasi istikrar küresel ve bölgesel düzende meşruiyet ve güç arasında rasyonel bir denge gerektirmektedir. Gücün ulusal veya ekonomik çıkar güdüsüyle meşruiyeti dışlaması veya kendi lehine evirmesi, yine bu gücün karşı güçlerle dengelenememesi ulusal ve uluslararası istikrarı bozmakta terörizmi, "küresel" veya yerel iç savaşın bir argümanı haline getirmektedir. Bu konuda dikkat çekilen önemli bir husus bu felaketlerle boğuşan toplumların çoğunluğunun Batı'nın (ABD ve Avrupa Güçleri) nüfuz alanında yer almasıdır. Eski SSCB nüfuz alanında terör eylemleri ve iç çatışmalar diğerine kıyasla yok denecek kadar azdır. Çeçenistan istisnai bir saha olarak sona ermiş, Ukrayna ise Batılı provokatif bir sürece maruz kalmıştır (Robert 2016: 21-34).

Stratejik tutum hibritleşmiş, doğrudan konvansiyonel eylemlerle/tutumla gayri nizami harbin/terörizmin dolaylı tutumu birbirlerine karşılıklı olarak alan açmaktadır (mutual simbiyoz ${ }^{6}$ ). Hegemonya tesisine yönelik küresel askeri müdahaleler "devletin koruma sorumluluğu" başlığı altında meşruiyet arayışındadır.

Bu savaş türünün aktörlerinin evrenselci, dini, etnik/ayrılıkçı motivasyon ile hareket etmeleri Terörizm çeşidi veya türü yaratmaz. Hedef ülke veya yapının belirli bir süre veya mekânda müşterek hedef olarak seçilmesi kolektivite veya ittifak doğurur. Yeni bir savaş türünü ortaya çıkaran faktörler stratejik tutum ile bağlantılıdır. Bunların yanısıra çevreci terör, bireysel terör, medya terörü gibi insanların güvenliğini tehlikeye düşüren eylem kavramsallaştırmalarının Terörizm ile bağlantısı olmayan şiddet türleri olarak düşünülmesi bu savaş türünün belirgin karakterinin muğlaklaştırılmasını önleyecektir.

Eski dönemlerden farklı olarak stratejik çözümlemelerde problem sahalarının her birini ayrı özelliğine göre ele almak artık mümkün değildir. Stratejik bir yönelim olan terörizm hem

\footnotetext{
${ }^{5}$ George Friedman Dünyanın en önde gelen istihbarat şirketi STRATFOR' un kurucusu ve CEO'sudur.

${ }^{6}$ Mutualizm, iki ayrı türün karşılıklı yarar sağladıkları ortak yaşam şeklidir. Mutualizm, genellikle, farklı olan gereksinimlerini birbirinden tamamlayan organizmalar arasında görülür. Simbiyoz terimi "birlikte yaşama" demektir. İki farklı türe ait bireyin ya da popülasyonun birlikte yaşamasına simbiyoz adi verilir.
} 
ulusal hem de uluslararası pek çok düzenlemede hukukî bir sorun şeklinde ele alınmıştır (Pazarc1 2000: 149) Ancak bu tür düzenlemeler hem illegal bir savaş türü olması hem de savaş bağlamından koparılması nedeniyle terörizmin profilini silikleştirmektedir. Terörizmin eylem kipi terör birileri içindir, belirli bir stratejik tutumla bağlantılıdır ve birilerinin değişik ölçekli amaçlarına hizmet eder. Bıggıo'nun terörist eylemlerin yıkıcı sonuçları ve ulusal güvenliğe, bölgesel istikrara yönelttiği tehdit nedeniyle, hukukî bir sorun olmaktan ziyade savaş eylemi niteliğinde olduğu ve benzer şekilde terörizme karşı devam eden mücadelenin hukukî bir uygulama değil, devam eden bir savaş olarak görülmesi gerektiği (Biggio 2002: 17) ifadesi tamamen gerçeği yansıtmaktadır. Gelişen durum bunu doğrulamaktadır. $\mathrm{Bu}$ bağlamda Terörizme yönelik olarak bir ülkeye dayatılan tanımlama şekilleri rakip oyuncuya kendi kuralları ile oyunu oynatma tutumundan başka ciddi bir içerikten yoksundur.

Bir gözü kapalı ve tek eksenli bakış kasıtlı, yönlendirilmiş veya kültürel olarak yapılandırılmış antagonistik tutumdur. Yönetimlere her alanda olduğu gibi terörün kavramsallaştırılması zemininde de dayatılan bu sığ ve tek eksenli bakış açısı Bordieu'nun belirttiği gibi stratejileri gizleyen stratejilerin neler olduğunun farkına varılmasını gerektirmektedir (Bourdieu 1999: 35). Ulusal kamuoyuna tek eksenli bakış açısının benimsetme, bu bağlamda medya ve STK'ları kullanma gayretleri yönetimleri baskılama, strateji üretimi ve uygulamasında sürtünme yaratma amacına yönelik psikolojik harp yaklaşımı ile bağlantılı görünmektedir.

"Uluslararası" veya "global/küresel" terörizm ifadesi mekân belirtmekten öte özne/failden yoksundur. Pasifize edici ve yönlendirici referans olarak öne sürülen "Uluslararası Toplum" bir hayaleti andırdığ 1 Trouillot'un betimlemesinde yerini bulmaktadır; "Uluslararası toplum bana çağdaş siyasette bir tür Grek Korosu gibi geliyor. Onu gören olmamıştır ama arkada şarkısını söyler ve herkes ona göre oynar" (Trouillot 2015: 230). Terörizmin strateji ve savaş bağlamından farklı alanlarda "çerçevelenmesi" ve bu yöndeki baskı akademik alanda sorun yaratmaktadır. Terörizmi betimlemede paralaksın giderilerek olgunun gerçek konumu ve durumunun tespit edilebilmesi, kırılma açısını giderebilecek konum değişikliğinin gerçekleşmesine, sığ görüşten kurtularak üç boyutlu derin görüşün kazanılması da iki gözün açık olmasına bağlıdır. Terörizmi birey ve grup davranışlarına indirgemek, dar tanımlara hapsetmek, muğlak ve görünür olmayan bir kamuya atfetmek, birileri ya da bir şeyi kimliksizleştirmek, savaşı ve taraflarını örtmektedir. 


\section{Kaynakça}

AGAMBEN, G. "Der Gewahrsam Ausnahmezustand als Weltordnung", Frankfurter Allgemeine Zeitung, 19.04.2003, Nr. 92, S. 33 http://www.ls1.soziologie.unimuenchen.de/dateien/2015/agaamben.pdf (Erişim Tarihi: 23.07.2017)

AGAMBEN, G. (2008), Olağanüstü Hal. (K. Atakay, Çev.) İstanbul: Varlık.

AMIN, S. (2014) Liberal Virüs, Sürekli Savaş ve Dünyanın Amerikanlaşması, İstanbul, Yordam Kitap

AMIN, S. (2016), Modernite, Demokrasi ve Din, (Çev. F. Başkaya vd.), İstanbul, Yordam.

ARON,R. (1969), The Evolution of Modern Strategic Thought, içinde Problems of Modern Strategy: Part I, Papers from the ISS 10th Annual Conference, The Adelphi Papers, Volume 9, Issue 54, London.

BAUDRILLARD J. (2002 a), "Das ist der vierte Weltkrieg", 15.01.2002 http://www.spiegel.de/kultur/ Jean gesellschaft/jean-baudrillard-das-ist-der-vierteweltkrieg-a-177013-2.html (Erişim Tarihi 12.04.2017)

BAUDRILLARD, Jean. (2002 b), Der Geist des Terrorismus (Çev. M Sedlaczek, vd.), Wien, Passagen Verlag.

BAUDRILLARD, J. (2011), Çaresiz Stratejiler, (2.b), (O. Adanır Çev.), İstanbul, Boğaziçi Üni.

BEKLİOĞLU, M. Kasım-Aralık 2010, Türkiye'nin İklim Değişikliğine Uyum Kapasitesinin Geliştirilmesi Birleşmiş Milletler Ortak Programı Bildirisi, http://limnology.bio.metu.edu.tr/sites/limnology.bio.metu.edu.tr /files/Beklioglu.pdf (Erişim Tarihi 12.10.2015).

BERNAU, O. "Landgrabbing: Neokolonialer Landraub in Afrika. Der globale Widerstand wächst", 02.05.2012, http://www.forumcivique.org/de/artikel/landgrabbingneokolonialer-landraub-afrikader-globale-widerstand-w\%C3\%A4chst (Erişim Tarihi, 11.02.2017).

BIGGIO, F. A: (2002), "Neutralizing the Threat: Reconsidering Existing Doctrines in the Emerging War on Terrorism", Case W. Res. J. Int'l L., Vol. 34.

BORDIEU, P. (1975), "The. Specificity of the Scientific Field and the Social Conditions of the Progress of Reason", içinde The Science Studies Reader, (ed. Mario Biagioli), New York, Routledge 1999.

BOSTANOĞLU, B. (2008),Türkiye-ABD İlişkilerinin Politikası, Ankara, İmge.

CLINE, R.ve ALEXANDER, Y. (1986). Terrorism as State Sponsored Covert Warfare, Hero Books.

CRITCHLEY, S. (2013), İmansızların İmanı, Siyasal Teoloji Deneyleri, İstanbul, Metis.

ÇAKMAK, H. (2008) Terörizm, Ankara, Platin, 2008.

ÇİFTÇI, İ. ve SEVİNÇ B.(2015), Uzakdoğu'dan Güney Asya'ya Şiddet ve Terörizm, Ankara, Karınca.

DAVIS, M. "Planet of Slums, Urban Revolotion and Informal Proletariat" New Left Review, 26, (Mart/Nisan) 2004 
DOUHET, G. (1983), The Command of the Air, Çev. Dino Ferrari, Washington D.C. US Government Printing Office.

GUEVARA, E. C., Gerilla Savaşı, (2.b.), (Çev. S. Doğru, R.K.Büyükişman), İstanbul, Everest, 2011.

ENGDAHL, F. W. Ölüm Tohumları, Genetik Biliminin Arkasındaki Karanlık Oyunlar, (4.b), (Çev. Ö. Şulekoğlu), İstanbul, Bilim.

ERGÜN, O. "Postmodern Jeopolitik ve Küresel Tasarının Eleştirel Çözümlemesi”, Türkiye Adalet Akademisi Dergisi, Y11:6, Nisan 2015, Say1:21, ss: 405-443.

AY, Hakan ve ERGÜN, O. "Türkiye'nin Gelecek Sorunu: Stratejik Açık”, CBÜ Sosyal Bilimler Dergisi, Y11 : 2014 Cilt :12 Say1 :2

EROL, M. Seyfettin, Uluslararası İlişkiler Aktörü Olarak Terör Örgütleri, içinde Terörizm, ed. Haydar Çakmak Ankara, Platin, 2008,

FAO, Food and Agriculture Organization Of The United Nations, The State of Food Insecurity in the World, http://www.fao.org/3/a-i4646e.pdf (Erişim Tarihi 07.07.2016).

FM 3,0 (Operation) - 2001

FREEDMAN, L.(2015), Strateji, (Çev. B. Dışbudak ve T. Belge), İstanbul, Alfa.

FRIEDMAN, G. (2011), Gelecek 10 Y11, Neredeydik, Nereye Gidiyoruz? (Çev. T. Törüner), İstanbul, Pegasus.

GRAY C. S. (2008), Modern Strateji, (Çev.H. Öz) Truva, İstanbul.

GÖÇMEN, A. Peter Mayo ile Söyleşi (2013): Sömürgecilik en eski kapitalist yöntemdir, http://www.muratkaymak.com/?pnum=527\&pt=Peter\%20 \%20ile\%20S\%C3\%B6yle\% C5\%9Fi (Erişim Tarihi: 21.01.2017)

Mayo

HAN, B.-Chul. (2016). Şiddetin Topolojisi, (Çev. D. Zaptçıŏlu), İstanbul, Metis.

HENDERSON, H.(2001) Global Terrorism The Complete Reference Guide, Chackmark Books, New York.

Homeopati Derneği, http://www.organon-homeopati-dernegi.org/alternatif-tip/ (Erişim 02.08.2017).

HOSBAWM, E. (2008). Küreselleşme, Demokrasi ve Terörizm, İstanbul, Yordam

HUPE ,Strausz R. (1942). Geopolitics: The Struggle for Space and Power.aktaran Friedrich KORKISCH W. "Globale Strategie: Die Geopolitik der USA", Österreichische Militärische Zeitschrift, In dieser Onlineausgabe, Şubat 2010, s.3, (Erişim tarihi 20.02.2018).

KEDİKLİ, U.(2013), Uluslararası Terörizm ve Devlet Sorumluluğu, Ankara, Nobel.

KISSINGER, H. (2016), Dünya Düzeni, (Çev. S.S. Gül), İstanbul, Boyner Yy. 2016.

KİSSINGER, H. (2011), Diplomasi, (Çev. B. Bayram), (10.bas.), İstanbul: Türkiye İş Bankası Kültür.

KOSELLECK, R. (1982), Geschichtliche Grundbegrife. Historisches Lexikon zur politischsozialen Sprache in Deutschland. Bd. 3 Stuttgart. 
KOSELLECK, R. 2006), Begrifsgeschichten. Studien zur Semantik und Pragmatik der politischen und sozialen Sprache. Frankfurt a.M.

KÖNİ, H. (2016), Kaos, Batı Hâkimiyetinin Çöküşü, (2.b) Wizart, İstanbul.

LIND, W. vd. (1989). The Changing Face of War. Into the Fourth Generation, The Marine Corps Gazette, Ekim.

MAIER, G. "Der Stratege des 21. Jahrhunderts, Die Renaissance prinzipienorientierter" Strategielehre https://www.oemzonline.at/display/ZLIintranet/Der+Stratege + des $+21 .+$ Jahrhunderts (Erişim Tarihi 12.03.204).

MANN, M. ve Hall John A. (2014), Yirmibirinci Yüzyılda İktidar, İstanbul, Aç1lım.

MARISCHKA, C. (2008), "Rüsten für den globalen Bürgerkrieg" http://www.imionline.de/download/IMI-Studie-2007-08.pdf (Erişim Tarihi: 21.07.2017)

MÜNKLER, H. (2003), "Die Neuen Kriege. Privatisierung und Kommerzialisierung kriegerischer Gewalt und Ihre Folgen“, Vortrag bei Berliner SPD am 26.03.2003, http://fa1.spd-berlin.de/Textversionen/muenk1.pdf ,(Erişim tarihi, 12.02.2017).

NOSTHOFF Anna-Verena ve Maschewski Felix, Ékstasis gegen Stásis oder: Der Krise widersprechen, http://www.engagee.org/assets/\%C3\%A9-2_\%C3\%A9kstasis-gegenst\%C3 \% A1 sis_maschewski_nosthoff.pdf. (Erişim Tarihi 06.06.2016).

NYE, J. S. (27.06.2011). "Mächtige Umverteilung”. (K. Ridderbusch, Röportaj1 Yapan) drradio, http://www.dradio.de /dlf/sendungen/andruck/1492095/ (01.09.2017).

Oakland Enstitüsü, 18.02.2014, http://www.oaklandinstitute.org/press-release-wall-streetbanks-eye-american-farmland-threaten-future-us-agriculture (Erişim Tarihi 10.03.2014).

Oakland Enstitüsü, Press Release: "Wall Street Banks Eye American Farmland, Threaten Future of U.S. Agriculture",18.02.2014, http://www.oaklandinstitute.org/pressrelease-wall-street-banks-eye-american-farmland-threaten-future-us-agriculture (Erişim Tarihi 10.03.2016).

ÖZKAN, Y. BBC, 16 Kasım 2015, Paris saldırıları: Molenbeek nasıl 'cihatçıların merkezi' oldu? http://www.bbc.com Statistik Portal, "Einwanderung in ausgewählte Länder weltweit in den Jahren 1871 bis 1911" http://de.statista.com/statistik/daten/studie /467096/umfrage/ einwanderung-in-ausgewaehlte-laender-weltweit/ (Erişim Tarihi 06.05.2016).

PARENTI, C. (2011), Tropic of Chaos: Climate Change and New Geography of Violence, Perseus Books, NY.

PAZARCI, H. (2000), Uluslararası Hukuk Dersleri, (IV. Kitap), Turhan Kitabevi, Ankara.

POST, J. M. ve ROBİNS, R. S. (2001), Politik Paranoya, Nefretin Psikopolitiği (Çev. İ. Kurmuş), İstanbul, Doğan Kitap.

RAY C. ve Yonah Alexander, (1986), Terrorism as State Sponsored Covert Warfare, Hero Books.

ROBERTS, P. C. (2016), Yeni Muhafazakâr Tehdit, Doğu Avrupa'dan Orta Doğu'ya Washington'un Üstünlük Savaşı, (Z.Anlı Çev.), İstanbul, Say. 
SARIBAY, A. Y. (2013), Demokrasinin Sosyolojisi, (3.b). Sentez, Ankara.

SCHELLING, T. C. (1966), Arms and Influence, New York, Yale Uni. Press, 1966.

SCHNEIDER, C. Bürgerrechte im 'Weltbürgerkrieg', Linke Schule, Erfurt, 15.08.2008, http://www.die-linke-bw.de/fileadmin/lv/lag-s/buergerrechte-und-demokratie/ Protokolle/20090329_Protokoll-Anhang_Text_Schneider.pdf (Erişim Tarihi: Temmuz 2016)

SHANK, M. "The Dangers of Soft Power, Government backed cultural programs often come across as just propaganda", 14.04.2014, http://www.usnews.com/opinion/blogs/worldreport/2014/04/14/when-us-soft-power-becomes-propaganda (Erişim Tarihi 10.01.2017)

Sputnik Zeitungen, USA analysieren russische „Hybrid-Krieg“-Technologie http://de.sputniknews.com/zeitungen/20150213/ 301098956.html, NATO Brief, Hybride Kriegsführung - hybride Reaktion? http://www.nato.int/docu/review/2014/Russia-Ukraine-Nato-crisis/Russia-Ukrainecrisis-war/de/index.htm NATO Basın Açıklaması, ed. Matthıs Nass, "Die Zeit, "Das neue Gesicht des Krieges" 12.03.2015 http://www.zeit.de /2015/11/nato-ukrainekrieg-russland (Erişim Tarhi 15.05.2016).

STURMER, M. Internationalen Instituts für Strategische Studien (IISS) Londra Uzmanları, Röportaj, (11.02.2015), yayınlayan Die Welt, Röportaj1 yapan "Experten warnen vor "hybrider Kriegsführung, http://www.welt.de/ politik/ausland/ article137341869/ Experten-warnen-vor-hybrider-Kriegsfuehrung.html, (Erişim tarihi 20.02.2015).

Statistik Portal, "Einwanderung in ausgewählte Länder weltweit in den Jahren 1871 bis 1911" http://de.statista.com/statistik/daten/studie/467096/umfrage/einwanderung-inausgewaehlte-laender-weltweit/ (Erişim Tarihi 06.05.2016)

Sur, Melda, (2011), Uluslararası Hukukun Esasları, (5.b.) İstanbul, Beta.

TOSCANO, A. (2013) Fanatizm, çev. B. Özkul, İstanbul: Metis.

TURLEY Jonathan, Congress Investigates "Slush Fund" At USAID Used To Get Lawmakers To Pass Reforms" http://www.informationclearinghouse.info/article38253.htm (Erişim Tarihi 10.01.2015).

TZU Sun, The Art of War çev. Lionel Giles, M.A. (1910), eBookMall 2002

UNHCR, Global Trends - Jahresbericht 2015, https://www.unofluechtlingshilfe.de/fluechtlinge/zahlen-fakten.html (Erişim Tarihi 03.07.201)

United Nations Population Division (UNPD), Department of Economic and Social Affairs,http://www.un.org/en/development/desa/population/publications/pdf/environm ent/PopulationConsumptionEnvironment2015.pdf (Erişim Tarihi 10.04.2016).

United Nations Population Division (UNPD), Department of Economic and Social Affairs, World Urbanization Prospects The 2014 Revision, http://esa.un.org/unpd/wup/Highlights/WUP2014-Highlights.pdf http://esa.un.org/unpd/wup/DataQuery/ United Nations New York, 2014, (Erişim Tarihi 21.12.2015)

UNHCR, Global Trends - Jahresbericht 2015, https://www.unofluechtlingshilfe.de/fluechtlinge/zahlen-fakten.html (Erişim Tarihi 03.07.2016) 
WARDEN III, J. A. (1993) "Strategic Warfare: The Enemy as a System", Concepts in Airpower for the Campaign Planner, Ed. Albert U. Mitchum, , Maxwell AFB, Alabama, Air Command and Staff College.

WEBSTER, C. ve F. (1961), Noble, The Strategic Air Offensive Against Germany, London, Her Majesty's Stationery Office, C. 4.

WENDT, A. (2016), Uluslararası Siyasetin Sosyal Teorisi, (2.b), (Çev.H.Ertem vd.), İstanbul.

WILDAWSKY, A. (1988) "Why Self-interest Means Less Outside of a Social Context", Journal of Theoretical Politics, 6, ss. 131-159.

WITTE, E. H. (2001), Theorien Zur Sozialen Macht, Sozialpsychologie, Psychologisches Institut I der Universität Hamburg, HAFOS, 2001 NR. 30.

YARGER, H. (2006), Strategic Theory for 21st Century: The Little Book on Big Strategy, Carlisle, PA U.S. Army War College, Strategic Studies Institute.

ŽIŽEK, S. (2014), Paralalaks, (2.b) (Çev. S. Gürses) İstanbul, Encore. 